\title{
Implementation of Anti-Dumping and Countervailing Duty
}

\section{(Cases of the United States Anti-Dumping and Countervailing Measures Implementation on Certain Coated Paper from Indonesia)}

\author{
Shagi Algivary ${ }^{1 *}$ and Rouli Anita Velentina ${ }^{1}$ \\ ${ }^{1}$ Faculty of Law, Universitas Indonesia, Depok, Jawa Barat, Indonesia \\ *Corresponding author. Email: shagialgivary@gmail.com
}

\begin{abstract}
In economic terms, globalization leads to the increasing interdependence of world economies through free trade. To ensure global trade commences freely and fair, World Trade Organization was created. The WTO creates and embodies the ground rules for global trade, especially when a country faced with unfair trade practices, such as dumping and subsidy. Antidumping actions and Countervailing measures are instruments for the protection of domestic industries created by World Trade Organization to prevent dumping and subsidy that can threaten or cause injury to an industry. Regulation of antidumping and countervailing measures set out in the agreement on the application of Article VI GATT 1994 and agreement on subsidies and countervailing measures Dumping practices prohibited by World Trade Organization is the sale of similar goods lower than normal prices that can threaten or cause injury to domestic industry, and subsidy practices prohibited by World Trade Organization is a specific financial contribution from government that can threaten or cause injury to an industry. Indonesia, as one of the members of World Trade Organization, has ratified the convention articles from the World Trade Organization by act No. 7 of 1994, including anti-dumping code and subsidies and countervailing measures. The ratification of the agreement obligates each member of World Trade Organization to implement the agreement in their national act. This paper analyzes the implementation of the agreement on the cases of the United States Anti-dumping and countervailing measures Implementation on certain coated paper from Indonesia.
\end{abstract}

\section{Keywords: International Trade Law, Dumping, Subsidy, Law Protection}

\section{INTRODUCTION}

Dumping and Subsidy are recognized as unfair trade practices by World Trade Organization. Even though it is recognized as unfair trade practices, not all dumping and subsidy are prohibited. Anti-dumping actions and Countervailing measures are instruments for the protection of domestic industries created by World Trade Organization to prevent dumping and subsidy that can threaten or cause injury to an industry. Indonesia, as one of the members of World Trade Organization, has ratified the convention articles from the World Trade Organization by act No. 7 of 1994, including anti-dumping code and subsidies and countervailing measures. The ratification of the agreement obligates each member of World Trade Organization to implement the agreement in their national act. There are two issues of concern that has been debated in literature to the determination of anti-dumping and countervailing duty.

The first issue relates to the deviation in the determination of dumping and subsidy in international and
Indonesian law and practices. Dumping and Subsidy that are not permissible are the ones that can threaten or cause injury to domestic industry. Dumping that prohibited or actionable by antidumping law is selling abroad at a price that is less than the price used to sell the same goods at home (the normal or fair value) and must threaten or cause material injury to an industry in the export market (Folsom and Gordon, 1995:127). The subsidy that prohibited by agreement on subsidies and countervailing measures is export subsidies and subsidies for the use of domestic products to remove its rival, the importing products. There is also actionable subsidy, its subsidy that can threaten or cause injury to domestic industry.

The second one is, although Antidumping and countervailing measures seem to be biased in favour of domestic industries, there are procedures that must be followed before the implementation. These procedures must be followed to prevent the misuse of the protection instrument. The misuse of the protection instrument can make unfair trade competition, as it harms the other party. If the other party feels that their misuse of the protection 
instrument, they can make a claim to Dispute Settlement Body (DSB) in World Trade Organization. The objective of the paper is to evaluate this concern in the context of Indonesia versus United States case.

In response to countervailing and antidumping duty petitions filed on September 23, 2009, by Appleton Coated, LLC ("Appleton"), NewPage Corp. ("NewPage"), and Sappi Fine Paper North America, domestic producers of coated paper, and the United Steel, Paper and Forestry, Rubber Manufacturing, Energy, Allied Industrial and Service Workers International Union, AFL-CIO, CLC (the "USW"), which represents workers involved in the production of coated paper, the Commission determined on November 10, 2010, that a domestic industry was threatened with material injury by reason of subject imports from Indonesia. The U.S. Department of Commerce issued antidumping and countervailing duty orders on November 17.

On March 13, 2015, the government of Indonesia requested consultations under the WTO Dispute Settlement Understanding in connection with the antidumping and countervailing duty determinations by the Commission and the Department of Commerce. Indonesia subsequently requested the establishment of a Panel in this matter, and the Panel was composed in 2016.

Indonesia claims that the Commission's the findings that the GOI provides standing timber for less than adequate remuneration and that the GOI log export ban confers a benefit are inconsistent with Article 14(d) of the SCM Agreement because the USDOC made a per se determination of price distortion based solely on the predominant market share of standing timber from public forests, the GOI "knowingly allowed an affiliate of a debtor to buy back its own debt in contravention of Indonesian law" is inconsistent with Article 12.7 of the SCM Agreement, the USDOC's findings of specificity are inconsistent with Article 2.1(c) of the SCM Agreement because the USDOC did not determine that the collection of stumpage fees, the log export ban, or the alleged forgiveness of debt were part of a plan or scheme intended to confer a benefit.

Indonesia also claim that the threat of injury determination is inconsistent with Article 3.7 of the Antidumping Agreement and Article 15.7 of the Agreement on Subsidies and Countervailing Measures because the Commission "relied on allegation, conjecture, and remote possibility rather than facts," and because the Commission "did not base its determination on a change in circumstances that was clearly foreseen and imminent." Indonesia also claims that the Commission's threat of injury determination is inconsistent with Article 3.5 of the AD Agreement and Article 15.5 of the SCM Agreement because the Commission "did not demonstrate the existence of a causal relationship between the imports and the purported threat of injury to the domestic industry,".

\section{MAIN ISSUES}

1. How is the compatibility of the determination of dumping and subsidy in Indonesia Antidumping and Countervailable Regulation and the WTO Regulation?

2. How is Indonesia Versus United States Case according to Anti-Dumping Agreement and Agreement of Subsidies and Countervailing Measures?

\section{DISCUSSION \& ANALYSIS}

\subsection{Basic Understanding of Dumping}

In economic terms, dumping is the terminology that used in international trade as trade practice done by the exporters by selling the commodity in international market at a price lower than the price it normally charges, this practice can disturb the market and parasites the producer competitors in the importing country. Black's Law Dictionary also defines dumping as the act of selling quantity at a very low price or practically regardless of the price; also selling goods abroad at less than the market price at home (Black, 1990:502).

Dumping has two effects to an Industry, good effects and bad effects. The good one happens when there is twoways dumping of differentiated goods between advanced and rich countries. It is sustainable, leads to higher consumption standards, and provided added incentives for technological innovations. The bad one happens when the dumping is likely to be disruptive for the importing country. It happens when the dumping product inventories become excessive and drive foreign competitors out of business. Producers of importing countries will face a slump in demand with disastrous spillover effects for the rest of the economy.

Dumping that prohibited or actionable by law is dumping that likely to be disruptive for the economy of the importing country. According to Antidumping Code, antidumping measures can only be issued if the dumping product causing injury and there is a causal relationship between the dumped imports and the injury to the domestic industry. Ralph H, Folsom and Michael W. Gordon (1995:127) also stated that "to be unlawful, dumping must threaten or cause materiil injury to an industry in the export market, the market price where price is lower. Dumping is recognized by most of the trading world as an unfair practice (again to price discrimination as an antitrust offense).".

\subsection{Definition of Dumping by World Trade Organization}

General Agreement on Tariffs and Trade (GATT 1947) also defines unlawful dumping as products of one country are introduced into the commerce of another country at less 
than the normal value of the products, is to be condemned if it causes or threatens material injury to an established industry in the territory of a contracting party or materially retards the establishment of a domestic industry. Article 2.1 Agreement on Implementation of Article VI 1994 or Antidumping Code, dumping product defined as a product introduced into the commerce of another country at less than its normal value, if the export price of the product exported from one country to another is less than the comparable price, in the ordinary course of trade, for the like product when destined for consumption in the exporting country.

Like stated before, the export price must be compared with comparable price. There are three ways to find comparable price for benchmark:

a. By comparing to Like Product in importer country. According to Article 2.6 Antidumping Code, the term like product mean a product which is identical, alike in all respects to the product under consideration, or in the absence of such a product, another product which, although not alike in all respects, has characteristics closely resembling those of the product under consideration. With regard to the characteristic of the products, an analysis must be done by considering many aspects such as the similarity of the usage, can that product substitute each other, the similarity of the distribution path, price comparison of the products, and the similarity of the production (Syahyu, 2004: 68).

b. Article 2.2 Antidumping Code stated that if there are no like products in domestic industry, export prices shall be determined by comparison with a comparable price of the like product when exported to an appropriate third.

c. In cases where there is no export price or where it appears to the authorities concerned that the export price is unreliable because of association or a compensatory arrangement between the exporter and the importer or a third party, the export price may be constructed on the basis of the price at which the imported products are first resold to an independent buyer, or if the products are not resold to an independent buyer, or not resold in the condition as imported, on such reasonable basis as the authorities may determine.

\subsection{Definition of Dumping by Indonesia Regulation}

Article 1.4 of Government Regulation Number 34 Year 2011 defines dumping products as imported products sell less than its normal value of the export price of the product exported from the exporting country. Article 1.6 of the regulation stated that the term "Normal value" in the provision is defined as the sales of the like product destined for consumption in the domestic market. If there are no sales of the like product in the domestic market, normal value can be determined by using the sales of like product in third country or by calculating the total cost of production, administration fees, and profit (constructed value).
Article 1.5 stated that the term "Export Price" in the provision is the true sales of product that imported to Indonesia Customs. According to Yulianto Syahyu (2004:75), there are three methods to determine export price. The first method is based on the price importer paid for. If the transaction is done fairly (arm lenght), then the price is reduced by components like discounts, tax, and delivery fees. The second method is based on Constructed Exporter Price; this method can only be applied when the first method can't be applied. As stated in Antidumping Code, the export price may be constructed on the basis of the price at which the imported products are first resold to an independent buyer, or if the products are not resold to an independent buyer, or not resold in the condition as imported. The last method is based on any reasonable basis; this method can only be applied when the first two methods can't be applied. If the first two methods can't be applied, the authorities may determine the export price based on any reasonable basis.

\subsection{Margin Dumping}

Before antidumping measures issued, margin dumping must be determined. As stated in Article VI GATT 1947, in order to offset or prevent dumping, a contracting party may levy on any dumped product an anti-dumping duty not greater in amount than the margin of dumping in respect of such product. Both WTO and Indonesia Regulations defines margin dumping as the price difference between normal value and export price.

Normal or fair value is the price that should normally be for the like products in the domestic market of the exporting country. The term "normal value" used because there can be situations, for example, where there is no market in the country of origin, where there is no market for the particular product in that country, where there are no sales of the same product by the producing exporter in the country of origin, or, where there are sales in the country of origin but the costs or prices are materially distorted. As there may not be a price, or an appropriate price, or even a market, in the country of origin, the law requires that dumping be measured on the basis of the normal value in the country (rather than the market) of origin. To calculate normal value, the equation that can be used is cost production plus profit divided by the total of production (Sood, 2011:127).

Export price is the price of the dumping product that the imported paid. Indonesia and WTO have differences method to determine export price. According to Article 2.5 of Antidumping Code, if the products are not imported directly from the country of origin but are exported to the importing Member from an intermediate country, then the export prices used is from the like product of the third country where the product directly imported. However, comparison may be made with the price in the country of origin, if, for example, the products are merely transhipped through the country of export, or such products are not produced in the country of export, or there is no comparable price for them in the country of export. 
According to the Explanation of Article 18 of Indonesian Custom Law Year 1995, there are three methods to determine the export price. The first method is based on the price importer paid for. If the transaction is done fairly (arm lenght), then the price is reduced by components like discounts, tax, and delivery fees (Syahyu, 2004: 72-73). The second method is based on Constructed Exporter Price, this method can only be applied when the first method can't be applied. As stated in Antidumping Code, the export price may be constructed on the basis of the price at which the imported products are first resold to an independent buyer, or if the products are not resold to an independent buyer, or not resold in the condition as imported. The last method is based on any reasonable basis; this method can only be applied when the first two methods can't be applied. If the first two methods can't be applied, the authorities may determine the export price based on any reasonable basis.

\subsection{Injury in Antidumping Regulation}

In Indonesia Antidumping Regulation and Antidumping Code, the words "injury" is taken as material injury to a domestic industry, threat of material injury to a domestic industry or material retardation of the establishment of such an industry. A threat of injury is defined as a situation in which the dumping would cause material injury that can be clearly foreseen and imminent based on facts and not merely on allegation, conjecture or remote possibility.

According to Article 3.1 Antidumping Code, the determination of injury shall be based on positive evidence and involve an objective examination of both the volume of the dumped imports, the effect of the dumped imports on prices in the domestic market for like products, and the consequent impact of these imports on domestic producers of such products. By that statement, there are three elements that have to be investigated before we can determine if the injury exists. The elements are the volume of dumped imports, the like products in the domestic markets, and the impact of the dumped imports makes.

According to Article 3.2 Antidumping Code, with regard to the volume of the dumped imports, the investigating authorities shall consider whether there has been a significant increase in dumped imports, either in absolute terms or relative to production or consumption in the importing Member. With regard to like products in the domestic markets, an analysis must be done by considering many aspects such as the similarity of the usage, can that product substitute each other, the similarity of the distribution path, price comparison of the products, and the similarity of the production. With regard to the impact of the dumped import makes, the examination of the impact of the dumped imports on the domestic industry concerned shall include an evaluation of all relevant economic factors and indices having a bearing on the state of the industry, including actual and potential decline in sales, profits, output, market share, productivity, return on investments, or utilization of capacity; factors affecting domestic prices; the magnitude of the margin of dumping; actual and potential negative effects on cash flow, inventories, employment, wages, growth, ability to raise capital or investments.

\subsection{Basic Understanding of Subsidy}

In economic terms, subsidy defined as a transfer of money from the government to an entity that leads to a fall in the price of the subsidized product. Black Laws Dictionary also defines subsidy as a grant made by the government, to any enterprise whose promotion is considered to be in the public interest (Black, 2004: 4480). Although governments sometimes make direct payments (such as cash grants), subsidies are normally indirect and take the form of research-and-development support, tax breaks, provision of raw materials at below-market prices, or low-interest loans or low-interest export credits guaranteed by a government agency.

Generally, there are two types of subsidy export subsidies and domestic subsidies (Barceló, 1980: 261). Traditionally, GATT has been more hostile to export than to domestic subsidies. Export subsidy appears aggressive, especially to an importing country facing serious market disruption from imports. Although the exporting country will almost never aim such subsidies specifically at a troubled market, the subsidy nevertheless represents a direct attempt by the subsidizing government to gain a greater share of foreign markets. Export subsidies can also help national products climb foreign tariff walls. Such subsidies may thus seem to subvert the legitimate tariff policy of an importing country.

Domestic subsidies are not as vulnerable to arguments of aggressiveness and inefficiency. Domestic subsidies are the counterpart of domestic taxes, which, unlike tariffs, are not closely regulated by GATT. Although domestic subsidies may increase the subsidizing country's export flow, they generally carry none of the aggressive overtones of export subsidies. They are normally aimed at legitimate internal socio-economic goals, not at expanding the country's share of foreign markets.

Black Laws Dictionary defines countervailable subsidy as A foreign government's subsidy on the manufacture of goods exported to another country, giving rise to the importing country's entitlement to impose a countervailing duty on the goods if their import caused or threatens to cause material injury to domestic industry (Black, 2004: 4480).

\subsection{Definition of Subsidy according to World Trade Organization}

Article 1.1 of the Agreement on Subsidies and Countervailing Measures, subsidy is defined as any form of income or price support or a financial contribution by a government where a government practice involves a direct transfer of funds (e.g. grants, loans, and equity infusion), potential direct transfers of funds or liabilities (e.g. loan guarantees); government revenue that is otherwise due is 
foregone or not collected (e.g. fiscal incentives such as tax credits); a government provides goods or services other than general infrastructure, or purchases goods; a government makes payments to a funding mechanism, or entrusts or directs a private body to carry out one or more of the type of functions which would normally be vested in the government and the practice, in no real sense, differs from practices normally followed by governments, or any form of income or price support, and a benefit confered. According to Article 1.2 of SCM Agreement, subsidy also has to be specific to be prohibited or countervailable.

In Article 2.1 of SCM Agreement, subsidy is considered specific to an enterprise, industry, or group of enterprises or industries if they applied these principles. The first one is when the granting authority, or the legislation pursuant to which the granting authority operates, explicitly limits access to a subsidy to certain enterprises, such subsidy shall be specific. The second one is where the granting authority, or the legislation pursuant to which the granting authority operates, establishes objective criteria or conditions governing the eligibility for, and the amount of, a subsidy, specificity shall not exist, provided that the eligibility is automatic and that such criteria and conditions are strictly adhered to. The criteria or conditions must be clearly spelled out in law, regulation, or other official documents, so as to be capable of verification. The third one is when there are reasons to believe that the subsidy may, in fact, be specific, other factors may be considered. Such factors are the use of a subsidy program by a limited number of certain enterprises, predominant use by certain enterprises, the granting of disproportionately large amounts of subsidy to certain enterprises, and the manner in which discretion has been exercised by the granting authority in the decision to grant a subsidy. The last one is when there is a subsidy that is limited to certain enterprises located within a designated geographical region within the jurisdiction of the granting authority.

From the provisions, the types of specificity divided into three different types (Barutu, 2007: 72). The first one is enterprise specificity, it is when the subsidies located to an enterprise or group of enterprises. The second one is industry specificity, it is when the subsidies located to an industry or group of industries. The last one is regional specificity, it is when the subsidies located within the designated geographical region.

Subsidy also divided subsidies into three kinds, prohibited subsidies; actionable subsidies; and nonactionable subsidies. According to Article 3.1 of SCM Agreement, subsidies that prohibited are subsidies contingent, in law or in fact, whether solely or as one of several other conditions, upon export performance or upon the use of domestic over imported goods. These provisions shall not have effects for developing countries in a period of five years and for undeveloped countries in a period of eight years since the agreement takes effect.

With regard of Countervailable Subsidies, according to Article 5 of SCM Agreement, countervailable subsidies defined as subsidies that can cause injury to the domestic industry, nullification or impairment of benefits accruing directly or indirectly, or serious prejudice to the interests of another Member. Serious prejudice in the agreement shall be deemed to exist if the total ad valorem subsidization of a product exceeding 5 percent; subsidies to cover operating losses sustained by an industry; subsidies to cover operating losses sustained by an enterprise, other than one-time measures which are non-recurrent and cannot be repeated for that enterprise and which are given merely to provide time for the development of long-term solutions and to avoid acute social problems; or direct forgiveness of debt, in example forgiveness of government-held debt, and grants to cover debt repayment.

With regard of non-countervailable subsidies, according to Article 8 of SCM Agreement, non-countervailable subsidies defined as subsidies which are not specific within the meaning of Article 2 of SCM Agreement and subsidies in form of assistance for research activities conducted by firms or by higher education or research establishments on a contract basis with firms. The assistance covers must not more than 75 percent of the costs of industrial research or 50 percent of the costs of pre-competitive development activity. There are also other non-actionable subsidies such as assistance to disadvantaged regions within the territory of a Member given pursuant to a general framework of regional development and assistance to promote adaptation of existing facilities to new environmental requirements imposed by law and/or regulations which result in greater constraints and financial burden on firms but only limited to 20 percent of the cost of adaptation.

\subsection{Definition of Subsidy by Indonesian Law}

Indonesia law does not give a detailed specification for countervailable subsidy. Article 1.8 of Government Regulation Number 34 Year 2011 defines countervailable subsidy as any financial contribution given by the government, directly or indirectly to companies, industries, or exporter. The subsidy can also in any form of price support on income that given directly or indirectly to raise export or to decrease import. There is also a term called "Subsidi Netto" in Article 1.9, it is the amount of the subsidy found in subsidized product. No countervailing duty shall be levied on any imported product in excess of the amount of subsidy. The amount of subsidy can be determined by calculating the difference between Subsidy and any kind of fee that paid for the subsidy or any kind of fee that paid for the export to replace the subsidy for the exporting product.

\subsection{Cases}

\subsubsection{Determination of Subsidy}

The claim Indonesia makes about the provides standing timber for less than adequate remuneration and that the GOI $\log$ export ban are inconsistent with Article 14(d) of the 
SCM Agreement is not true. GOUS used Malaysia standing timber price as a benchmark for the adequacy of remuneration. The Indonesian government argued that, based on Article 14 (d) Agreement on Subsidies and countervailing Measures, GOUS should have calculated the amount of benefit based on in-country prices for raw materials and not out-of-country prices as a benchmark. Indonesia sides argument can't be applied because there are about $93.73 \%$ of harvested timber in Indonesia grows on government-owned lands. This statement is also backed by a research conducted by Food And Agriculture Organization Of The United Nations in 2005, showed the total land area of Indonesia was 187.9 million ha. Of this, 133.6 million ha of the total land area are state- owned forest areas (or 72\%) and 54.3 million ha are non-forest areas (or 28\%). Furthermore, the Indonesian government sets and administrates all possible stumpage fees and, thus, controls the supply of standing timber. The timber market is monopolized by Indonesia Government so there is no competition in the market. So there are no available marketdetermined in-country prices for timber, it is not possible to calculate the amount of benefit relying on in-country prices.

About the GOI "knowingly allowed an affiliate of a debtor to buy back its own debt in contravention of Indonesian law" is inconsistent with Article 12.7 of the SCM Agreement, Indonesia claimed that the GOUS were not able either to confirm or deny the affiliation between APP and Orleans. According to Article 6.1(d) of SCM Agreement, the debt forgiveness itself is considered as a subsidy that can cause serious prejudice. Based on Indonesia Law, Article 1.1(b) SKKBPPN No. 7 Year 2001, it is also prohibited to sell assets to companies that previously owned such assets or their affiliates. During the investigation period, the GOUS repeatedly asked APP and the government of Indonesia to provide information on the affiliation between APP and Orleans. However, the GOUS did not receive any information in this regard. Therefore, the GOUS used the facts provided during the investigation by other interested parties, in particular, a newspaper article and World Bank report to prove that APP and Orleans were affiliated.

With regards of Indonesia Claim that the GOUS findings of specificity are inconsistent with Article 2.1(c) of the SCM Agreement, the claim can be accepted. In October 2001, the Ministry of Forestry and Ministry of Trade and Industry enacted a new regulation to ban export of any logs from Indonesia. The main objective of this regulation is to combat the illegal export of logs, to boost the development of forestbased manufacturing industries, and to lower the level of deforestation. This regulation considered important because of the high level of deforestation in Indonesia. The purpose of the regulation is backed up with the research from many institutes that said that illegal logging continues to be a major cause of deforestation in Indonesia. The United Nations estimated that illegal logging occurs in 37 of Indonesia's 41 national parks and in 2001, illegally logged timber accounted for $80 \%$ of the total national harvest.
From the explanation, even if the subsidy does exist, it is considered as industry specificity. According to Article 2.1(c) of the SCM Agreement, the factors that have to be considered as the reason of subsidy may be specific are use of a subsidy program by a limited number of certain enterprises, predominant use by certain enterprises, the granting of disproportionately large amounts of subsidy to certain enterprises, and the manner in which discretion has been exercised by the granting authority in the decision to grant a subsidy. The Log Export Ban is not limited to a number of enterprises, it applies to every enterprise dealing with Log. Even if it can be argued that $\log$ Export Ban is limited to a number of Industries, the Article also stated that the extent of diversification of economic activities within the jurisdiction of the granting authority, as well as of the length of time during which the subsidy program has been in operation shall be considered too. According to Research conducted by Australian University in 2006, the effect of Log Export Ban for Indonesia Economic is not beneficial for the country because it lowers the country's GDP and induces lower incomes. Therefore, based on Article 1.1(b) of the SCM Agreement, the log export ban can't be determined as a subsidy because there is no benefit is thereby conferred.

\subsubsection{Determination of Threat of Injury}

Indonesia claim that the GOUS threat of injury determination is inconsistent with Article 3.7 of the AD Agreement and Article 15.7 of the SCM Agreement because the Commission "relied on allegation, conjecture, and remote possibility rather than facts," and because the Commission "did not base its determination on a change in circumstances that was clearly foreseen and imminent." Indonesia also claims that the Commission's threat of injury determination is inconsistent with Article 3.5 of the AD Agreement and Article 15.5 of the SCM Agreement because the Commission "did not demonstrate the existence of a causal relationship between the imports and the purported threat of injury to the domestic industry. All Indonesia claims about the injury can't be considered as true.

According to Article 3.7 of the AD Agreement and Article 15.7 of the SCM Agreement, there are factors that must be considered to determine a threat of injury. For dumping cases, the factors are significant rate of increase of dumped imports into the domestic market indicating the likelihood of substantially increased importation; sufficient freely disposable, or an imminent, substantial increase in, capacity of the exporter indicating the likelihood of substantially increased dumped exports to the importing Member's market, taking into account the availability of other export markets to absorb any additional exports; whether imports are entering at prices that will have a significant depressing or suppressing effect on domestic prices, and would likely increase demand for further 
imports; and inventories of the product being investigated. For subsidy cases, the factors are nature of the subsidy or subsidies in question and the trade effects likely to arise therefrom; a significant rate of increase of subsidized imports into the domestic market indicating the likelihood of substantially increased importation; sufficient freely disposable, or an imminent, substantial increase in, capacity of the exporter indicating the likelihood of substantially increased subsidized exports to the importing Member's market, taking into account the availability of other export markets to absorb any additional exports; whether imports are entering at prices that will have a significant depressing or suppressing effect on domestic prices, and would likely increase demand for further imports; and inventories of the product being investigated.

According to Certain Coated Paper Suitable for HighQuality Print Graphics Using Sheet-Fed Presses from China and Indonesia Investigation Nos. 701-TA-470-471 and 731TA-1169-1170 (Final), The GOUS determined that there is a reasonable overlap of competition that can cause injury to domestic industry based on four factors. The first factor is fungibility, There appears to be a reasonable degree of fungibility among the subject imports from each country and the domestic like product. The Second factor is Geographic Overlap, Indonesia importers of the coated paper reported selling nationwide in United State. The third one is channels of Distribution, the vast majority of U.S. producers' shipments of Certain Coated Paper and the vast majority of subject imports from each subject country were to merchants/distributors. The last one is the simultaneous presence, the record indicates that domestic producers' U.S. shipments, along with imports from Indonesia, have been simultaneously present in the U.S. market throughout the entire period of investigation. The four factors are linked with price factor that subject imports from Indonesia undersold the domestic like product by Underselling margins varying from 2.6 to 14.4 percent for subject imports from Indonesia. The consumption of subject imports from Indonesia in the United States each rose slightly from 2007 to 2008, increased at a greater rate from 2008 to 2009 . Based on the factors above, it can be concluded that the requirements to determine a threat of injury with the causal relationship are fulfilled.

\section{CLOSING}

\subsection{Conclusion}

Based on the explanation above, it can be concluded matters as follows. First, there are requirements to determinate which dumping and subsidy that considered as one of unfair trade practice that actionable or countervailable. The requirements are similar in International and Indonesian Laws. For dumping, not all dumping are bad or prohibited by World Trade Organization. There is dumping that can leads to higher consumption standards and provided added incentives for technological innovations. The Antidumping measures can only be applied to dumping that cause injury to domestic industry. For Subsidy, there are many types of subsidies according to World Trade Organization. Countervailing measures can only be applied to the types of prohibited subsidy and countervailable Subsidy.

Second, the misuse of the instruments for the protection can be claimed. If the other party feels that there is an inconsistency between the use of the instrument of protection with the regulation that covers it, they can make a claim to Dispute Settlement Body in World Trade Organization. In the case of Indonesia versus United State, one of Indonesia claim about the specificity of Log Export Ban can be accepted. The main objective of the regulation is to combat the illegal export of logs, to boost the development of forest-based manufacturing industries, and to lower the level of deforestation and it is considered important because of the high level of deforestation in Indonesia. The regulation also can't be determined as a subsidy because there is no benefit thereby conferred.

\subsection{Suggestion}

The Government of Indonesia have to be more serious about handling dumping or subsidy accusation. The DSB Panel confirmed the lawfulness of the decision made by the GOUS and one of the reasons is because the GOI unsuccessfully argued that prohibition of log exports was a possible solution to mitigate deforestation and illegal logging. It took the GOI five years to make a claim to Dispute Settlement Body and yet the GOI still unsuccessfully argued that prohibition of log exports was a possible solution to mitigate deforestation and illegal logging. This behaviour must be removed because it can bring damage to the growth of the Indonesia Industry.

\section{REFERENCES}

[1] Barutu, Christhophorus. Ketentuan Antidumping, Subsidi, dan tindakan pengamanan (safeguard) dalam GATT dan WTO. Bandung: PT Citra Aditya Bakti, 2007.

[2] Black, Henry Campbell. Black's Law Dictionary. Minnesota: West Publishing, 1990.

[3] Black, Henry Campbell. Black's Law Dictionary. Ed.8. Minnesota: West Publishing, 2004.

[4] Folsom, Ralph H. and Michael W Gordon. International Bussiness Transactions. Minnesota: West publishing, 1995.

[5] Kumar, Raj. International Economics. New Delhi: Excel Books, 2008.

[6] Bosche, Peter van den. Pengantar Hukum WTO. Jakarta: Yayasan Obor Indonesia, 2010. 
[7] Sood, Muhammad. Hukum Perdagangan Internasional. Depok: Raja Grafindo, 2011.

[8] Sukarmi. Regulasi Anti Dumping di Bawah Bayang-bayang Pasar Bebas. Jakarta: Sinar Grafika, 2002.

[9] Syahyu, Yulianto. Hukum Anti-Dumping di Indonesia. Jakarta: Penerbit Ghalia Indonesia, 2004.

[10] Cahyadi, Ni Made Ayu Krisna and Made Sukarsa. "Faktor- faktor yang Mempengaruhi Ekspor Kertas dan Barang Berbahan Kertas Di Indonesia Tahun 1988-2012” E-Journal Ekonomi Pembangunan, Vol. 4, No. 1 (January 2014). Page. 63-70.

[11] Barceló III, John J. "Subsidies, Countervailing Duties and Antidumping After the Tokyo Round" Cornell International Law Journal, Vol. 13: Issue 2, Article 5 (Summer 1980) Page 257-288.

[12] Barceló III, John J." Subsidies and Countervailing Duties--Analysis and a Proposal", Cornell International Law Journal (January 1977) Page 779-853.

[13] Resodarmo, Budy P. and Arief Anshory Yusuf. "Is The Log Export Ban Efficient Instrument for Economic Development and Environmental Protection? The Case of Indonesia" Asian Economic Papers 5:2 (2006). page 75-104.

[14] Times, The Economic. "Definition of Subsidy" https://economictimes.indiatimes.com/definition/su bsidy, accessed on 1 June 2019

[15] Institute, World Resource. "Indonesia's Deforestation Dropped 60 Percent in 2017, but There's More to Do" https://www.wri.org/blog/2018/08/indonesiasdeforestation-dropped-60-percent-2017-theresmore-do, accessed on 7 May 2019 